\title{
The Role of the Cerebellum in Unconscious and Conscious Processing of Emotions: A Review
}

\author{
Silvia Clausi ${ }^{1,2}$, Claudia Iacobacci ${ }^{1,2,3}$, Michela Lupo ${ }^{1}$, Giusy Olivito ${ }^{1,4}$, Marco Molinari ${ }^{5}$ and \\ Maria Leggio ${ }^{1,2, *}$ \\ 1 Ataxia Laboratory, IRCCS Santa Lucia Foundation, Via Ardeatina 306, 00179 Rome, Italy; \\ s.clausi@hsantalucia.it (S.C.); claudia.iacobacci@uniroma1.it (C.I.); m.lupo@hsantalucia.it (M.L.); \\ g.olivito@hsantalucia.it (G.O.) \\ 2 Department of Psychology, Sapienza University of Rome, Via dei Marsi 78, 00185 Rome, Italy \\ 3 Ph.D. Program in Behavioral Neuroscience, Sapienza University of Rome, Via dei Marsi 78, \\ 00185 Rome, Italy \\ 4 Neuroimaging Laboratory, Santa Lucia Foundation, Via Ardeatina 306, 00179 Rome, Italy \\ 5 Neurorehabilitation 1 and Spinal Center, Robotic Neurorehabilitation Lab, IRCCS Santa Lucia Foundation, \\ Via Ardeatina 306, 00179 Rome, Italy; m.molinari@hsantalucia.it \\ * Correspondence: maria.leggio@uniroma1.it; Tel.: +39-06-4442-7645
}

Academic Editor: Peter Walla

Received: 30 January 2017; Accepted: 12 May 2017; Published: 17 May 2017

\begin{abstract}
Studies from the past three decades have demonstrated that there is cerebellar involvement in the emotional domain. Emotional processing in humans requires both unconscious and conscious mechanisms. A significant amount of evidence indicates that the cerebellum is one of the cerebral structures that subserve emotional processing, although conflicting data has been reported on its function in unconscious and conscious mechanisms. This review discusses the available clinical, neuroimaging, and neurophysiological data on this issue. We also propose a model in which the cerebellum acts as a mediator between the internal state and external environment for the unconscious and conscious levels of emotional processing.
\end{abstract}

Keywords: cerebellum; emotions; affects; conscious; unconscious; psychopathology

\section{Introduction}

Emotional alterations have long been recognized in patients affected by cerebellar pathology, but have received little attention [1-3].

In 1998, the characterization of 'cerebellar cognitive affective syndrome' (CCAS) by Schmahmann and Sherman [4] extended the function of the cerebellum to the cognitive and emotional domains, demonstrating that these alterations are unrelated to cerebellar motor deficits [4-7].

There has been considerable progress in cerebellar research over the past decade and an increasing number of studies have reported the function of the cerebellum in sensory and perceptual mechanisms [8-11] and in components of the motor hierarchy, which are separate from mere motor control $[12,13]$.

Moreover, many groups have provided evidence of emotional and autonomic impairments in patients with cerebellar pathologies [14-16], with several neuroimaging functional studies having also demonstrated cerebellar activation in emotional tasks [17-20].

The link between the cerebellum and the emotional domain is also supported by findings of structural and functional cerebellar abnormalities in pathologies that are characterized by emotional disorders, such as schizophrenia, autism, and mood disorders [16,21-24]. 
Cerebellar function in emotions must be viewed with regards to its anatomical and functional connections with the neural circuits that subserve various emotional domains [19,25-27]. It has been proposed that two neural systems are associated with emotional processing: one operating on an implicit level and another on an explicit level [28-32]. Whereas the cerebellum has been associated with information processing on an implicit level in other functional domains [33-35], it has been described as being involved in the implicit and explicit components of the emotional domain [36,37].

In cognitive science, the distinction between implicit and explicit processes corresponds to that between unconscious and conscious processes [38]. Emotional phenomena that are executed without conscious processing and occur automatically—such as peripheral physiological arousal—are considered to be implicit, whereas all emotional experiences that require processing at higher levels and evoke conscious feelings are defined as explicit [28,32].

Thus, according to this theoretical framework, the terms unconscious and implicit are synonymous, as are conscious and explicit in this report.

Despite the copious data on the cerebellum and emotional processes [39], the cerebellar involvement in unconscious and conscious components of emotions is still unclear.

In this article, we review the available clinical, neuroimaging, and neurophysiological data, to better clarify cerebellar function in these components of emotional processing.

This approach will increase our understanding of the function of the 'emotional cerebellum' in addition to providing insights into cerebellar involvement in behavioral control and in neuropsychiatric and mood disorders.

The following points will be highlighted:

- Emotional processing implies the existence of unconscious and conscious components.

- The cerebellum is connected to cerebral structures that are involved in unconscious and conscious emotional processing.

- In the unconscious component of emotions, cerebellar involvement is supported by its influence in modulating autonomic reactions, the automatic component of emotional learning, and implicit processing of facial expressions.

- In the conscious component of emotions, the involvement of the cerebellum is supported by its influence on the emotional content of fear conditioning, conscious processing of emotional facial expression, the ability to recognize negative emotions, and self-perception of negative emotions.

- In the emotional domain, measuring cerebellar function with regards to state estimation and its ability to process and predict sequential events allows us to compare internal and external events on the unconscious and conscious levels.

\section{Emotional Unconscious and Conscious Circuits}

It is generally recognized that emotional behaviors imply the existence of unconscious and conscious mechanisms [28,32,40-42]. These components can be defined separately using concepts and neuroanatomy, although they should be considered on the same continuum that subtends emotional awareness [32].

The unconscious process comprises the sensory and motor components of an emotional response that precedes an emotional feeling state. In comparison, the conscious process includes the bodily states on the periphery of awareness (background feelings), the attention to one's subjective emotional state (focal attention to feelings) and thoughts about the contents of conscious emotional experience (reflective awareness) [42]. The two systems share most neuroanatomical substrates, but additional networks are involved in conscious processing [32,41].

Among the various theoretical models of the neural substrates of emotional processing, it has been proposed that emotional processing arises in subcortical networks and then influences cortical activity. Automatic and unconscious emotional processing is mediated by the amygdala, pulvinar, and superior colliculus [43]. These structures process basic emotional stimuli to orient and initiate the physiological 
arousal that characterizes emotions [44-46]. Other structures that are involved in the processing of unconscious emotional information include the hypothalamus, basal ganglia, brainstem nuclei, and the ascending neurotransmitter systems [32]. The cortico-pulvinar-cortical pathway has been suggested to link fast subcortical processing and the cortical structures that participate in higher-order conscious processing of emotions [40]. The pulvinar is connected to the extrastriate cortex (occipital cortex), inferior temporal cortex, and temporo-occipital area [47]. It is also associated with the insula [48], posterior parietal cortex [49], medial frontal cortex [49,50], superior temporal gyrus [51], and cingulate gyrus [50]. Most of these structures are involved in conscious processing of emotions and are part of the well-known default-mode network (DMN) [52], which has been linked to cognitive-emotional integration [53], emotional regulation [54], and emotional valence identification [55].

The neuronal networks between subcortical and cortical areas are bi-directional, indicating that bottom-up and top-down processes must be considered: i.e., that conscious processing of emotional information can alter the operation of subcortical structures and vice versa [32].

The cerebellum is strongly connected to cerebral structures that are involved in unconscious and conscious emotional components: the reticular system (arousal), hypothalamus (autonomic function and emotional expression), limbic structures (emotional experience and expression), and cortical association areas (cognitive processing of emotions) [56]. In particular, it receives afferent nerves from the medial mammillary bodies $[57,58]$ and multi-modal deep layers of the superior colliculus in addition to being connected bi-directionally to the hypothalamus [59] and the brainstem areas (ventral tegmental area, periaqueductal gray, and locus ceruleus) that are related to the limbic and paralimbic regions [60]. The cerebellum receives information from the paralimbic cortices in the cingulate gyrus [61] via their projections to the pontine nuclei $[62,63]$. The caudal inferior parietal lobule, multi-modal portions of the superior temporal gyrus, and posterior parahippocampus contribute to the cortico-pontine projections through their connections with paralimbic structures $[64,65]$. Moreover, the cerebellum makes reciprocal connections with the prefrontal cortex [26]. Consistent with neuroanatomical findings, functional magnetic resonance imaging (fMRI) studies have demonstrated functional coherence between the cerebellum; the cerebral areas that mediate the processing of emotional information, such as the amygdala, hippocampus, hypothalamus, insula and anterior cingulate cortex; and cortical associative areas [27,66-68].

In the following paragraphs, we will present data that support the hypothesis of cerebellar involvement in the unconscious and conscious components of emotional processing (summarized in Table 1).

Table 1. Clinical, neuroimaging, and neurophysiological studies reporting cerebellar involvement in emotional domains.

\begin{tabular}{|c|c|c|c|c|c|}
\hline & Study & Subjects & Task & Emotional Data & $\begin{array}{l}\text { Unconscious/ } \\
\text { Conscious }\end{array}$ \\
\hline \multirow{6}{*}{ Clinical data } & $\begin{array}{l}\text { Annoni et al., } \\
2003 \text { [14] }\end{array}$ & $n=1$ left cb stroke & $\begin{array}{l}\text { - Clinical observation } \\
\text { - Skin conductance }\end{array}$ & $\begin{array}{l}\text { Emotional flattening and } \\
\text { impaired autonomic reactivity } \\
\text { to negative reinforcement }\end{array}$ & Unconscious \\
\hline & $\begin{array}{l}\text { Adamaszek et al., } \\
2014 \text { [69] }\end{array}$ & $\begin{array}{l}n=15 \text { with cb ischemic } \\
\text { lesion }\end{array}$ & - Tübingen affect battery & $\begin{array}{l}\text { Impaired recognition of } \\
\text { emotional facial expression }\end{array}$ & Conscious \\
\hline & $\begin{array}{l}\text { Clausi et al., } \\
2012 \text { [70] }\end{array}$ & $\begin{array}{l}n=10 \mathrm{cb} \text { with } \mathrm{dp} n=12 \\
\text { with major depression } \\
n=15 \mathrm{cb} \text { with no } \mathrm{dp}\end{array}$ & $\begin{array}{l}\text { - SCL-90 } \\
\text { - POMS } \\
\text { - HDS } \\
\text { - Self-mood monitoring }\end{array}$ & $\begin{array}{l}\text { Inability to evaluate the own } \\
\text { depressive mood }\end{array}$ & Conscious \\
\hline & $\begin{array}{l}\text { Clausi et al., } \\
2015 \text { [71] }\end{array}$ & $\begin{array}{l}n=15 \text { with cb atrophy or } \\
\text { focal cb damage }\end{array}$ & $\begin{array}{l}\text { - Gambling task } \\
\text { - Self-rating of regret }\end{array}$ & $\begin{array}{l}\text { Impaired ability to recognize } \\
\text { negative feelings of regret }\end{array}$ & Conscious \\
\hline & $\begin{array}{l}\text { D'Agata et al., } \\
2011 \text { [72] }\end{array}$ & $n=20$ with cb atrophy & - Ekman 60 faces test & Impairment in social emotions & Conscious \\
\hline & $\begin{array}{l}\text { Garrad et al., } \\
2008[73]\end{array}$ & $\begin{array}{l}n=15 \text { with cb atrophy } \\
\text { (SCA3/SCA6) }\end{array}$ & $\begin{array}{l}\text { - Emotion attribution } \\
\text { - Social situations } \\
\text { - ToM task }\end{array}$ & Impairment in ToM & Conscious \\
\hline
\end{tabular}


Table 1. Cont.

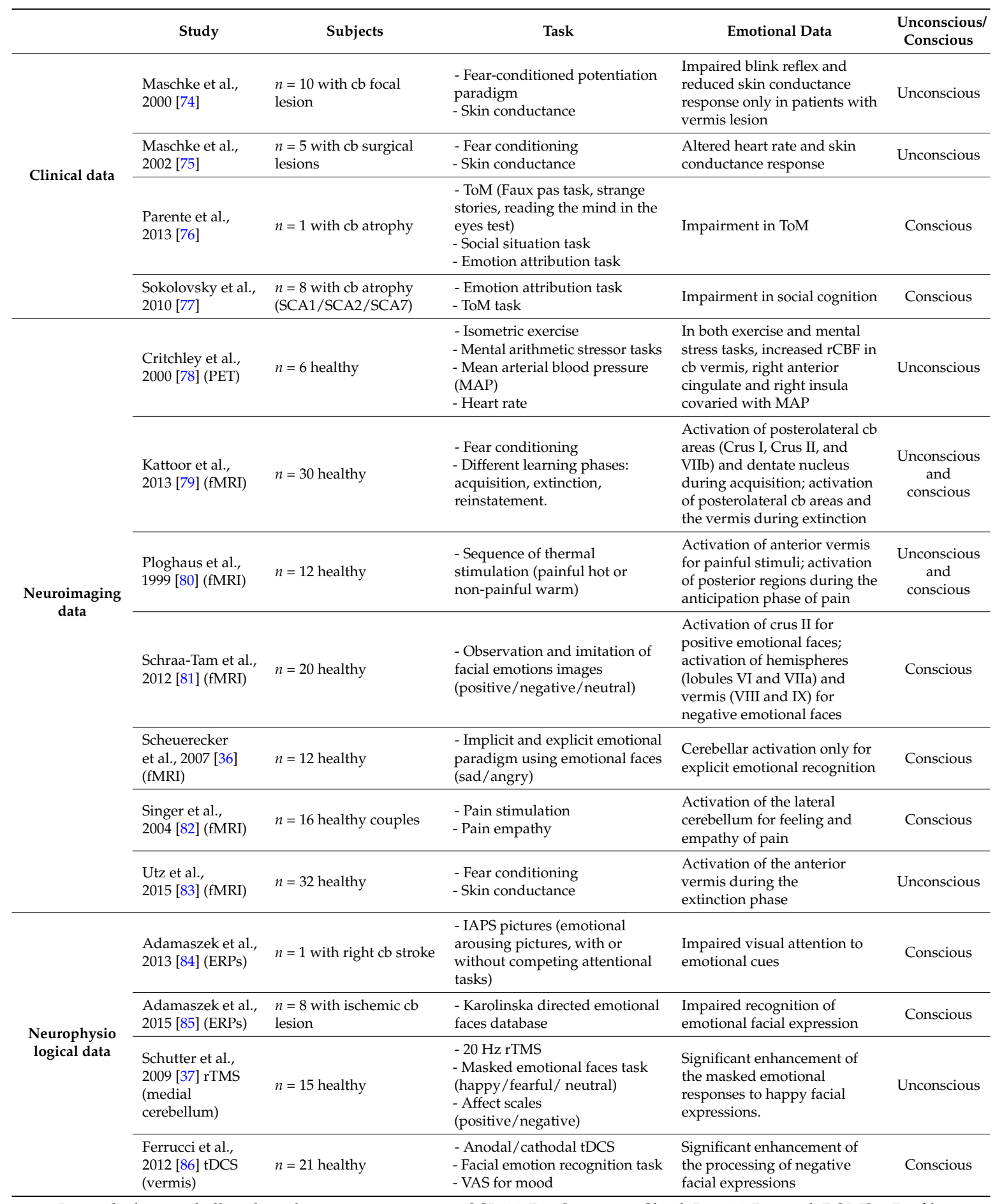

Legend: $\mathrm{cb}=$ cerebellar; $\mathrm{dp}=$ depressive symptoms; SCL-90-R = Symptom Check List-90-Revised; POMS = Profile of Mood State; HDS = Hamilton Depression Scale; SCA = Spino-cerebellar Ataxia; ToM = Theory of Mind; $\mathrm{PET}=$ Positron Emission Tomography; fMRI = functional Magnetic Resonance Imaging; VAS = visual analogue scale; ERPs = event-related potentials; IAPS = International Affective Picture System; rTMS = repetitive Transcranial Magnetic Stimulation; tDCS = transcranial Direct Current Stimulation. 


\section{Cerebellum and Emotional Processing}

\subsection{Cerebellar Involvement in the Unconscious Component of Emotions}

Cerebellar function in emotional responses at the unconscious level is supported by its influence on the modulation of autonomic reactions and the automatic components of emotional learning.

Based on clinical observations in patients affected by cerebellar damage, there is a lowered skin conduction response to negative stimuli [14] and an impaired blink reflex to fear stimuli [74]. Reports of impaired responsiveness of arterial blood pressure to aversive stimuli in animals [87] and a less extensive increase in heart rate during fear conditioning tasks in subjects with vermal lesions [75] indicate that the cerebellum is also involved in the autonomic neural pathways that subserve the cardiovascular system in emotion regulation [87-89]. Furthermore, fMRI studies have implicated that the cerebellar vermis is involved in autonomic responses that are associated with fear conditioning [78-80,83].

Fear is a crucial emotion and the capacity to develop fear-related memories has an important evolutionary advantage. The regulation of fear and fear memories consists of motor/autonomic components (changes in blood pressure and heart rate, dilation of pupils), endocrine, behavioral responses (freezing behavior, potentiated startle reflex) [90], and the affective component. It has been proposed that the cerebellar vermis mediates the conditioning of fear-related changes in autonomic functions, even in the absence of contingency awareness [90-92]. The central autonomic nuclei in the brainstem and cerebellum control the sympathetic and parasympathetic axes of the autonomic nervous system, allowing for the production of integrated somatic response patterns that are necessary for the metabolic support of emotional behavior [78].

The cerebellum is an important component in the central autonomic network [93], because the vermis is connected to the brainstem (catecholamine neurons) and hypothalamus [60].

Furthermore, the vermis is connected with limbic areas-such as the amygdala, hippocampus [90], periaqueductal gray $[94,95]$, and sensory cortices [96,97]—which function in emotional learning during fear conditioning and generate the appropriate emotional behavior patterns $[94,95]$.

Taking into account these connections, the vermis can be viewed as the interface between the sensory stimuli, emotional state, and motor responses of a subject. Thus, in the vermis, learning-related plasticity might be crucial for relaying the appropriate emotional and motor behaviors in response to sensory stimuli and maintaining this information for long periods. Consistent with this hypothesis, various animal studies have shown that the potentiation of excitatory $[98,99]$ and inhibitory [100] synapses that impinge on the same Purkinje cells correlates with associative fear learning. These changes at the cellular level have long-lasting effects and are related to associative processes.

Other data support cerebellar function in the unconscious components of emotional processes with regards to its involvement in the implicit processing of facial expression [37]. Schutter et al. [37] found that repetitive Transcranial Magnetic Stimulation (rTMS) over the midline cerebellum enhances the implicit processing of happy facial expressions, with no changes in consciously experienced mood. These findings have been explained by projections from the cerebellar vermis to the ventral tegmental area of the midbrain, thus modulating the mesolimbic areas through ventral tegmental dopaminergic projections [60] (see Table 1 for details on reported studies).

These data from various experimental approaches suggest that the cerebellum automatically modulates emotional behavior to remain within homeostatic baseline levels and according to the context.

Clinical studies in patients who are affected by 'cerebellar cognitive affective syndrome' (CCAS) and 'posterior fossa syndrome' (PFS) have noted impaired modulation of emotional and behavioral regulation, manifesting as emotional lability, changes in affect [4,6,101-109], and inappropriate laughing or crying [110-112]. These symptoms have been related specifically to damage to the vermis, which, based on its connections, has been termed the "limbic cerebellum" [21,64,113]. 


\subsection{Cerebellar Involvement in the Conscious Component of Emotions}

As discussed in the previous section, although the cerebellar vermis participates in fear-related somatic and autonomic aspects, the posterolateral hemispheres have been proposed to mediate the emotional content of fear conditioning at higher cognitive levels [114]. This assumption is supported by the presence of connections between the cerebellar hemispheres and the more ventral and caudal areas of the dentate nucleus, which in turn are connected to the temporal, parietal, and prefrontal cortices [115], which are involved in cognitive elaboration of emotional content [32].

Posterior regions of the cerebellum are activated during the anticipation [80], conscious feelings, and empathy of pain [82].

Furthermore, activation of the posterolateral cerebellar hemispheres is observed in the late acquisition phase of fear conditioning that is linked to the conscious elaboration of emotional content of associative learning $[79,114]$.

Consistent with these findings, the cerebellum appears to be involved in more complex functions that are inherent to emotions and affects.

This idea is supported by neurophysiological data that show a connection between the cerebellum and higher-order cerebral domains $[84,85]$. Whereas cerebellar input to autonomic pathways travels along a closed neuronal loop, event-related potentials (ERP) data has characterized the cerebellum in higher-order emotional processing as an active interface with large-scale cerebral pathways that are involved in emotionally conscious processes, including recognition and response to cues with emotional valence. Impairments in visual emotional attention [84] and emotional face recognition [85] have been reported in subjects affected by cerebellar hemispheres damage.

Moreover, neuroimaging and neurostimulation studies have shown the involvement of the cerebellum in conscious processing of emotional facial expressions $[69,81,85]$.

The processing of emotion from facial expressions requires various psychological processes that are controlled by a wide array of cerebral structures [116], which involve both unconscious and conscious processes $[17,78]$. Facial perception is defined as "higher-level visual processing of faces" [117], involving perception and recognition of the emotional meaning [118]. Facial expressions are crucial to non-verbal social interactions and are markers of an internal state or an intention $[119,120]$. Recognizing facial expressions is vital in a complex social world as it permits one to detect the emotional state of another person and provides cues on how to respond in social situations [121,122].

As discussed in the previous section, the cerebellum has been linked to the implicit processing of facial expressions. However, fMRI studies have shown that the cerebellum is also activated in addition to the amygdala and prefrontal cortex during conscious processing of emotional faces $[17,36]$.

These findings are not surprising, considering that the cerebellum belongs to a widespread network, including the amygdala-medial prefrontal circuitry, which contributes to determine the meaning of external stimuli and to facilitate cortical processes to react to them coherently $[17,123]$. Specifically, the medial prefrontal cortex is involved in emotional self-awareness, playing a key role in complex aspects of emotional processing, such as social interaction [124]. The amygdala is associated with the perception of emotion, specifically faces [118] and emotional arousing effects [125-128].

Direct support of the hypothesis of cerebellar function in the conscious processing of emotional faces comes from stimulation studies that have observed a greater ability to recognize negative facial expressions after transcranial direct current stimulation (tDCS) is performed over the cerebellum [86].

Clinical studies in patients with cerebellar damage have also highlighted the involvement of the cerebellum in emotional recognition, allowing proper social cognition regardless of stimulus (visual or auditory), particularly for negative emotions [69,72], and in more complex social cognition domains. This has become known as the Theory of Mind (ToM) [73,76,77].

Cerebellar function in the conscious mechanisms of emotional processing has been evidenced by its incorporation into the complex neural circuits that are involved in the cognitive functions $[5,26]$ needed for defining and expressing the emotional state in oneself or in others. The experience of feeling is fundamentally influenced by one's conscious awareness and interpretation of one's 
mood [129], requiring interdependence between emotion and cognition that is sustained by the extensive interconnections between the limbic system and the cortical association areas [130] to which the cerebellum is strongly connected.

Cerebellar recruitment in the conscious component of emotional behavior, related to the awareness of one's affective state and the interpretation of one's mood, has been observed as a loss in self-perception of emotions in the presence of cerebellar pathology [70,71,131]. In recent studies, we found that patients with cerebellar damage were unable to feel conscious emotions of regret as a consequence of their disadvantageous choices in a gambling task [71] or to explicitly recognize their bad mood in the presence of clinically relevant depressive disorder [70,131] (see Table 1 for details on reported studies).

\section{Discussion}

To understand cerebellar function in the various mechanisms that underlie emotions, we must consider that emotional processing involves various physiological, cognitive, and behavioral components. As discussed, emotional processing is usually triggered by the unconscious and conscious perception of internal or external events, and by cognitive judgments [132,133]. It is associated with changes in body states (i.e., skeletal muscle activity, visceral organs, facial expressions) that are preparatory for adaptive behavioral responses [134-137]. These alterations can result in conscious feelings that imply a cognitive understanding of their conceptual emotional meaning. The internal states might be generated by our own choices or by external events and are characterized by emotional valence (positive or negative) $[138,139]$ that influences behavioral actions [140]. Emotional processing is also modulated by other cognitive systems, such as attention, reasoning, and memory [141,142].

Overall, the processing of emotional information implies bottom-up and top-down mechanisms that ensure coherence between emotional states following internal or external events and suitable behaviors for various social contexts.

These mechanisms are controlled by complex neuronal networks in which the cerebellum functions, as reported in the previous sections $[26,57,60,61,115]$.

Thus, the cerebellum might be a central component at which various information streams from and to the cerebral structures converge, subtending unconscious and conscious mechanisms of emotional processing.

The cerebellar vermis has been reported as the hub that perceives and forwards emotional cues in the subcortical-cortical networks [56] that are primarily involved in the unconscious stage of emotion, whereas the cerebellar hemispheres have been argued to be involved in high-order cognitive functions that allow conscious emotional processing to be linked to the internal state and perception of the external environment $[56,143]$.

Thus, the cerebellum is equipped for unconscious and conscious processing, contributing to internal representations of emotions in addition to the monitoring and integration of interoceptive and exteroceptive information.

We recently proposed the "sequence detection model" as an operational mode in which the cerebellum processes information that is related to several domains, including the emotional domain $[144,145]$. According to this model, the cerebellum compares disparate states, regardless of the domains that are involved (motor, cognitive, or emotional) [146]. In particular, the cerebellum detects and simulates repetitive patterns of temporally or spatially structured events, allowing the creation of internal models [147] and the prediction of incoming events [148]. Thus, this constantly tunes motor, behavioral, and emotional responses, based on the ever-changing environment [149].

Considering the function of the cerebellum in state estimation [146], we propose that in the emotional domain, this structure mediates the comparison between the internal state and external event, contributing to self-perception of an emotion that is coherent with the environment. Essentially, it intervenes when the subject must compare the basic emotional state (internal state) and the possible effect of an action or context (external event). 
In this framework, we have demonstrated that in estimating regret, a subject with cerebellar damage fails to compare the basic emotional state (internal state) that follows his decision and the state that is determined by the external event, based on a gambling result [71]. Similarly, in estimating mood state by a mood monitoring (MoMo) device [150], a subject who is affected by cerebellar damage is unable to recognize his bad mood state (internal state), which shows his inability to compare the internal state with the external negative or positive event $[70,131]$.

These observations are consistent with the cerebellar involvement in optimizing internal and external responses according to the environment, akin to a master regulatory structure for integrating motor, emotional, and sensory information that affects "mind-world synchronization" [151]. When cerebellar function is altered, the processing of information streams becomes desynchronized [147,151,152], providing a breeding ground for various psychopathological disorders, such as schizophrenia, autism, and depressive disorders, in which cerebellar dysfunctions have been reported [153-155]. For example, certain symptoms of schizophrenia and the dysregulation of mood homeostasis in depression disorders have been linked to a failure to compare internal and external representations [151].

The cerebellar dysfunction in these diseases further supports the hypothesis that cerebellar processing also participates in generating coherent and conscious representations of self-perception and the external world $[39,71,146,156]$.

Overall, the emotional and behavioral impairments in cerebellar patients and psychopathologies, in which structural and functional changes occur at the cerebellar level, might arise from an internal discrepancy between internally perceived and externally generated signals. This internal coherence at the unconscious and conscious levels is necessary to ensure an emotional behavior that is coherent with the environment and a self-perception of one's emotional state that is consistent with the context.

\section{Conclusions}

Following the theoretical framework above, emotional processing implies the existence of unconscious and conscious components that require complex bottom-up and top-down interactions [32]. These interactions are necessary to compare the expectations that are related to past emotional experiences or a social situation, with sensory inputs from the body states through feedforward and feedback signals. As evidenced in this review, the cerebellum participates in modulating the unconscious and conscious levels of emotional processing. This is understandable in the sequence detection theory, which implicates the cerebellum as a structure that compares disparate states to create internal models and predict events [144,145]. Thus, in the emotional domain, measuring cerebellar function with regards to state estimation and its ability to process and predict sequential events allows one to compare different states, integrating internal and external events at the unconscious and conscious levels. This is allowed by the cerebellar integrated functioning in the complex neural networks that subserve the unconscious and conscious components of the emotional domain [56-65].

This proposal opens new perspectives on cerebellar function in the etiopathology of neuropsychiatric and mood disorders and novel neuromodulatory therapeutic approaches.

Acknowledgments: This work was partially supported by grants from the Italian Ministry of Health to Marco Molinari (Grant Number RF-2011-02348213) and to Silvia Clausi (Grant Number GR-2013-02354888).

Author Contributions: Silvia Clausi and Maria Leggio conceived the review and wrote the paper; Silvia Clausi and Michela Lupo revised the clinical studies; Silvia Clausi and Giusy Olivito revised the neuroimaging studies; Claudia Iacobacci organized and provided the table of the manuscript. Silvia Clausi, Marco Molinari and Maria Leggio contributed to the discussion, analysis and completion of the manuscript.

Conflicts of Interest: The authors declare no conflict of interest. 


\section{References}

1. Prescott, J.W. Early somatosensory deprivation as ontogenic process in the abnormal development of the brain and behavior. In Medical Primatology 1970; Goldsmith, J., Moor-Jankowski, Eds.; Karger: Basel, Switzerland, 1971; ISBN: 13: 9789057022234.

2. Heath, R.G. Modulation of emotion with a brain pacemaker: Treatment for intractable psychiatric illness. J. Nerv. Ment. Dis. 1977, 165, 300-317. [CrossRef] [PubMed]

3. Heath, R.G.; Dempesy, C.W.; Fontana, C.J.; Myers, W.A. Cerebellar stimulation: Effects on septal region, hippocampus, and amygdala of cats and rats. Biol. Psychiatry 1978, 13, 501-529. [PubMed]

4. Schmahmann, J.D.; Sherman, J. The cerebellar cognitive affective syndrome. Brain 1998, 121, 561-579. [CrossRef] [PubMed]

5. Leiner, H.C.; Leiner, A.L.; Dow, R.S. Reappraising the cerebellum: What does the hindbrain contribute to the forebrain? Behav. Neurosci. 1989, 103, 998-1008. [CrossRef] [PubMed]

6. Exner, C.; Weniger, G.; Irle, E. Cerebellar lesions in the PICA but not SCA territory impair cognition. Neurology 2004, 63, 2132-2135. [CrossRef] [PubMed]

7. Buckner, R.L. The cerebellum and cognitive function: 25 years of insight from anatomy and neuroimaging. Neuron 2013, 80, 807-815. [CrossRef] [PubMed]

8. Sokolov, A.A.; Erb, M.; Gharabaghi, A.; Grodd, W.; Tatagiba, M.S.; Pavlova, M.A. Biological motion processing: The left cerebellum communicates with the right superior temporal sulcus. Neuroimage 2012, 59, 2824-2830. [CrossRef] [PubMed]

9. Sokolov, A.A.; Erb, M.; Grodd, W.; Pavlova, M.A. Structural loop between the cerebellum and the superior temporal sulcus: Evidence from diffusion tensor imaging. Cereb. Cortex 2014, 24, 626-632. [CrossRef] [PubMed]

10. Baumann, O.; Borra, R.J.; Bower, J.M.; Cullen, K.E.; Habas, C.; Ivry, R.B.; Leggio, M.; Mattingley, J.B.; Molinari, M.; Moulton, E.A.; et al. Consensus paper: The role of the cerebellum in perceptual processes. Cerebellum 2015, 14, 197-220. [CrossRef] [PubMed]

11. Ronconi, L.; Casartelli, L.; Carna, S.; Molteni, M.; Arrigoni, F.; Borgatti, R. When one is enough: Impaired multisensory integration in cerebellar agenesis. Cereb. Cortex 2017, 27, 2041-2051. [CrossRef] [PubMed]

12. Taig, E.; Küper, M.; Theysohn, N.; Timmann, D.; Donchin, O. Deficient use of visual information in estimating hand position in cerebellar patients. J. Neurosci. 2012, 32, 16274-16284. [CrossRef] [PubMed]

13. Casartelli, L.; Federici, A.; Cesareo, A.; Biffi, E.; Valtorta, G.; Molteni, M.; Ronconi, L.; Borgatti, R. The role of the cerebellum in high stages of motor planning hierarchy. J. Neurophysiol. 2017, 117, 1474-1482. [CrossRef] [PubMed]

14. Annoni, J.M.; Ptak, R.; Caldara-Schnetzer, A.S.; Khateb, A.; Pollermann, B.Z. Decoupling of autonomic and cognitive emotional reactions after cerebellar stroke. Ann. Neurol. 2003, 53, 654-658. [CrossRef] [PubMed]

15. Schutter, D.J.; van Honk, J. The cerebellum on the rise in human emotion. Cerebellum 2005, 4, $290-294$. [CrossRef] [PubMed]

16. Schmahmann, J.D.; Weilburg, J.B.; Sherman, J.C. The neuropsychiatry of the cerebellum-Insights from the clinic. Cerebellum 2007, 6, 254-267. [CrossRef] [PubMed]

17. Fusar-Poli, P.; Placentino, A.; Carletti, F.; Landi, P.; Allen, P.; Surguladze, S.; Benedetti, F.; Abbamonte, M.; Gasparotti, R.; Barale, F.; et al. Functional atlas of emotional faces processing: A voxel based meta-analysis of 105 functional magnetic resonance imaging studies. J. Psychiatry Neurosci. 2009, 34, 418-432. [PubMed]

18. Stoodley, C.J.; Schmahmann, J.D. Functional topography in the human cerebellum: A meta-analysis of neuroimaging studies. Neuroimage 2009, 44, 489-501. [CrossRef] [PubMed]

19. Stoodley, C.J.; Schmahmann, J.D. Evidence for topographic organization in the cerebellum of motor control versus cognitive and affective processing. Cortex 2010, 46, 831-844. [CrossRef] [PubMed]

20. Van Overwalle, F.; Baetens, K.; Mariën, P.; Vandekerckhove, M. Social cognition and the cerebellum: A meta-analysis of over $350 \mathrm{fMRI}$ studies. Neuroimage 2014, 86, 554-572. [CrossRef] [PubMed]

21. Schmahmann, J.D. Disorders of the cerebellum: Ataxia, dysmetria of thought, and the cerebellar cognitive affective syndrome. J. Neuropsychiatry Clin. Neurosci. 2004, 16, 367-378. [CrossRef] [PubMed]

22. Hoppenbrouwers, S.S.; Fitzgerald, P.B.; Chen, R.; Daskalakis, Z.J. The role of the cerebellum in the pathophysiology and treatment of neuropsychiatric disorders: A review. Brain Res. Rev. 2008, 59, 185-200. [CrossRef] [PubMed] 
23. Fatemi, S.H.; Aldinger, K.A.; Ashwood, P.; Bauman, M.L.; Blaha, C.D.; Blatt, G.J.; Chauhan, A.; Chauhan, V.; Dager, S.R.; Dickson, P.E.; et al. Consensus paper: Pathological role of the cerebellum in autism. Cerebellum 2012, 11, 777-807. [CrossRef] [PubMed]

24. Villanueva, R. The cerebellum and neuropsychiatric disorders. Psychiatry Res. 2012, 198, 527-532. [CrossRef] [PubMed]

25. Çavdar, S.; Şan, T.; Aker, R.; Şehirli, U.; Onat, F. Cerebellar connections to the dorsomedial and posterior nuclei of the hypothalamus in the rat. J. Anat. 2001, 198, 37-45. [CrossRef] [PubMed]

26. Middleton, F.A.; Strick, P.L. Cerebellar projections to the prefrontal cortex of the primate. J. Neurosci. 2001, 21, 700-712. [PubMed]

27. Habas, C.; Kamdar, N.; Nguyen, D.; Prater, K.; Beckmann, C.F.; Menon, V.; Greicius, M.D. Distinct cerebellar contributions to intrinsic connectivity networks. J. Neurosci. 2009, 29, 8586-8594. [CrossRef] [PubMed]

28. Damasio, A.R. Descartes' Error: Emotion, Reason, and the Human Brain; G.P. Putnam's Press: New York, NY, USA, 1994; ISBN: 0399138943.

29. Morris, J.S.; Ohman, A.; Dolan, J.R. Conscious and unconscious emotional learning in the human amygdala. Nature 1998, 393, 467-470. [CrossRef] [PubMed]

30. Whalen, P.J.; Rauch, S.L.; Etcoff, N.L.; McInerney, S.C.; Lee, M.B.; Jenike, M.A. Masked presentations of emotional facial expressions modulate amygdala activity without explicit knowledge. J. Neurosci. 1998, 18, 411-418. [PubMed]

31. Driver, J.; Vuilleumier, P.; Eimer, M.; Rees, G. Functional magnetic resonance imaging and evoked potential correlates of conscious and unconscious vision in parietal extinction patients. Neuroimage 2001, 14, 68-75. [CrossRef] [PubMed]

32. Lane, R. Neural substrates of implicit and explicit emotional processes: A unifying framework for psychosomatic medicine. Psychosom. Med. 2008, 70, 214-231. [CrossRef] [PubMed]

33. Molinari, M.; Leggio, M.G.; Solida, A.; Ciorra, R.; Misciagna, S.; Silveri, M.C.; Petrosini, L. Cerebellum and procedural learning: Evidence from focal cerebellar lesions. Brain 1997, 120, 1753-1762. [CrossRef] [PubMed]

34. Leggio, M.G.; Neri, P.; Graziano, A.; Mandolesi, L.; Molinari, M.; Petrosini, L. Cerebellar contribution to spatial event processing: Characterization of procedural learning. Exp. Brain Res. 1999, 127, 1-11. [CrossRef] [PubMed]

35. Menghini, D.; Hagberg, G.E.; Caltagirone, C.; Petrosini, L.; Vicari, S. Implicit learning deficits in dyslexic adults: An fMRI study. Neuroimage 2006, 33, 1218-1226. [CrossRef] [PubMed]

36. Scheuerecker, J.; Frodl, T.; Koutsouleris, N.; Zetzsche, T.; Wiesmann, M.; Kleemann, A.M.; Brückmann, H.; Schmitt, G.; Möller, H.J.; Meisenzahl, E.M. Cerebral differences in explicit and implicit emotional processing-An fMRI study. Neuropsychobiology 2007, 56, 32-39. [CrossRef] [PubMed]

37. Schutter, D.J.; Enter, D.; Hoppenbrouwers, S.S. High-frequency repetitive transcranial magnetic stimulation to the cerebellum and implicit processing of happy facial expressions. J. Psychiatry Neurosci. 2009, 34, 60-65. [PubMed]

38. Kihlstrom, J.F.; Mulvaney, S.; Tobias, B.A.; Tobis, I.P. The emotional unconscious. In Cognition and Emotion; Eich, E., Kihlstron, J., Bower, G., Forgas, J.P., Niedenthal, P.M., Eds.; Oxford University Press: New York, NY, USA, 2000; pp. 30-86. ISBN: 9780195113341.

39. Adamaszek, M.; D’Agata, F.; Ferrucci, R.; Habas, C.; Keulen, S.; Kirkby, K.C.; Leggio, M.; Mariën, P.; Molinari, M.; Moulton, E.; et al. Consensus Paper: Cerebellum and Emotion. Cerebellum 2017, 16, 552-576. [CrossRef] [PubMed]

40. Shobe, E.R. Independent and collaborative contributions of the cerebral hemispheres to emotional processing. Front. Hum. Neurosci. 2014, 8, 230. [CrossRef] [PubMed]

41. Smith, R.; Lane, R.D. The neural basis of one's own conscious and unconscious emotional states. Neurosci. Biobehav. Rev. 2015, 57, 1-29. [CrossRef] [PubMed]

42. Lane, R. Neural correlates of conscious emotional experience. In Cognitive Neuroscience of Emotion; Lane, R., Nadel, L., Ahern, G., Allen, J., Kaszniak, A., Rapcsak, S., Schwartz, G., Eds.; Oxford University Press: New York, NY, USA, 2000; pp. 345-370. ISBN: 0195155920, 9780195155921.

43. Gainotti, G. Unconscious processing of emotions and the right hemisphere. Neuropsychologia 2012, 50, 205-218. [CrossRef] [PubMed]

44. Johnson, M.H. Subcortical face processing. Nat. Rev. Neurosci. 2005, 6, 766-774. [CrossRef] [PubMed] 
45. Liddell, B.J.; Brown, K.J.; Kemp, A.H.; Barton, M.J.; Das, P.; Peduto, A.; Gordon, E.; Williams, L.M. A direct brainstem-amygdala-cortical 'alarm' system for subliminal signals of fear. Neuroimage 2005, 24, $235-243$. [CrossRef] [PubMed]

46. Tamietto, M.; de Gelder, B. Neural bases of the non-conscious perception of emotional signals. Nat. Rev. Neurosci. 2010, 11, 697-709. [CrossRef] [PubMed]

47. Shipp, S. The functional logic of cortico-pulvinar connections. Philos. Trans. R. Soc. Lond. B Biol. Sci. 2003, 358, 1605-1624. [CrossRef] [PubMed]

48. Mufson, E.J.; Mesulam, M.M. Thalamic connections of the insula in the rhesus monkey and comments on the paralimbic connectivity of the medial pulvinar nucleus. J. Comp. Neurol. 1984, 227, 109-120. [CrossRef] [PubMed]

49. Behrens, T.E.J.; Johansen-Berg, H.; Woolrich, M.W.; Smith, S.M.; Wheeler-Kingshott, C.A.; Boulby, P.A.; Barker, G.J.; Sillery, E.L.; Sheehan, K.; Ciccarelli, O.; et al. Non-invasive mapping of connections between human thalamus and cortex using diffusion imaging. Nat. Neurosci. 2003, 6, 750-757. [CrossRef] [PubMed]

50. Romanski, L.M.; Giguere, M.; Bates, J.F.; Goldman-Rakic, P.S. Topo-graphic organization of medial pulvinar connections with the prefrontal cortex in the rhesus monkey. J. Comp. Neurol. 1998, 37, 313-332. [CrossRef]

51. Eidelberg, D.; Galaburda, A.M. Symmetry and asymmetry in the human posterior thalamus. I. Cytoarchitectonic analysis in normal persons. Arch. Neurol. 1982, 39, 325-332. [CrossRef] [PubMed]

52. Van den Heuvel, M.P.; Mandl, R.C.; Kahn, R.S.; Pol, H.; Hilleke, E. Functionally linked resting-state networks reflect the underlying structural connectivity architecture of the human brain. Hum. Brain Mapp. 2009, 30, 3127-3141. [CrossRef] [PubMed]

53. Greicius, M.D.; Srivastava, G.; Reiss, A.L.; Menon, V. Default mode network activity distinguishes Alzheimer's disease from healthy aging: Evidence from functional MRI. Proc. Natl. Acad. Sci. USA 2004, 101, 4637-4642. [CrossRef] [PubMed]

54. Grimm, S.; Boesiger, P.; Beck, J.; Schuepbach, D.; Bermpohl, F.; Walter, M.; Ernst, J.; Hell, D.; Boeker, H.; Northoff, G. Altered negative BOLD responses in the default-mode network during emotion processing in depressed subjects. Neuropsychopharmacology 2008, 34, 843-932. [CrossRef] [PubMed]

55. Sreenivas, S.; Boehm, S.G.; Linden, D.E.J. Emotional faces and the default mode network. Neurosci. Lett. 2012, 506, 229-234. [CrossRef] [PubMed]

56. Schmahmann, J.D. The role of the cerebellum on affect and psychosis. J. Neurolinguist. 2000, 13, $189-214$. [CrossRef]

57. Haines, D.E.; Dietrichs, E. An HRP study of hypothalamo-cerebellar and cerebello-hypothalamic connections in squirrel monkey (Saimiri scieureus). J. Comp. Neurol. 1984, 229, 559-575. [CrossRef] [PubMed]

58. Aas, J.E.; Brodal, P. Demonstration of topographically organized projections from the hypothalamus to the pontine nuclei: An experimental study in the cat. J. Comp. Neurol. 1988, 268, 313-328. [CrossRef] [PubMed]

59. Haines, D.E.; Dietrichs, E.; Mihailoff, G.A.; McDonald, E.F. The cerebellar-hypothalamic axis: Basic circuits and clinical observations. Int. Rev. Neurobiol. 1997, 41, 83-107. [CrossRef] [PubMed]

60. Snider, R.S.; Maiti, A. Cerebellar contributions to the Papez circuit. J. Neurosci. Res. 1976, 2, $133-146$. [CrossRef] [PubMed]

61. Devinsky, O.; Morrell, M.J.; Vogt, B.A. Contributions of anterior cingulate cortex to behaviour. Brain 1995, 118, 279-306. [CrossRef] [PubMed]

62. Vilensky, J.A.; Van Hoesen, G.W. Corticopontine projections from the cingulate cortex in the rhesus monkey. Brain Res. 1981, 205, 391-395. [CrossRef]

63. Brodal, P.; Bjaali, J.G.; Aas, J.E. Organization of cingulo-ponto-cerebellar connections in the cat. Anat. Embryol. 1991, 184, 245-254. [CrossRef] [PubMed]

64. Schmahmann, J.D. From movement to thought: Anatomic substrates of the cerebellar contribution to cognitive processing. Hum. Brain Mapp. 1996, 4, 174-198. [CrossRef]

65. Schmahmann, J.D.; Pandya, D.N. The cerebrocerebellar system. Int. Rev. Neurobiol. 1997, 4, 31-60. [CrossRef]

66. Allen, G.; McColl, R.; Barnard, H.; Ringe, W.K.; Fleckenstein, J.; Cullum, C.M. Magnetic resonance imaging of cerebellar prefrontal and cerebellar-parietal functional connectivity. Neuroimage 2005, 28, 39-48. [CrossRef] [PubMed]

67. Roy, A.K.; Shehzad, Z.; Margulies, D.S.; Kelly, A.M.C.; Uddin, L.Q.; Gotimer, K.; Biswal, B.B.; Castellanos, F.X.; Milham, M.P. Functional connectivity of the human amygdala using resting-state fMRI. Neuroimage 2009, 45, 614-626. [CrossRef] [PubMed] 
68. Sang, L.; Qin, W.; Liu, Y.; Zhang, Y.; Jiang, T.; Yu, C. Resting-state functional connectivity of the vermal and hemispheric subregions of the cerebellum with both the cerebral cortical networks and subcortical structures. Neuroimage 2012, 61, 1213-1225. [CrossRef] [PubMed]

69. Adamaszek, M.; D’Agata, F.; Kirkby, K.C.; Trenner, M.U.; Sehm, B.; Steele, C.J.; Berneiser, J.; Strecker, K. Impairment of emotional facial expression and prosody discrimination due to ischemic cerebellar lesions. Cerebellum 2014, 13, 338-345. [CrossRef] [PubMed]

70. Clausi, S.; Aloise, F.; Contento, M.P.; Pizzamiglio, L.; Molinari, M.; Leggio, M. Un Holter per il monitoraggio del tono dell'umore giornaliero: Studio preliminare in soggetti con patologia cerebellare. In Proceedings of the Congresso Nazionale delle Sezioni dell'Associazione Italiana di Psicologia, Chieti, Italy, 20-22 September 2012; p. 121.

71. Clausi, S.; Coricelli, G.; Pisotta, I.; Pavone, E.F.; Lauriola, M.; Molinari, M.; Leggio, M. Cerebellar damage impairs the self-rating of regret feeling in a gambling task. Front. Behav. Neurosci. 2015, 9, 113. [CrossRef] [PubMed]

72. D'Agata, F.; Caroppo, P.; Baudino, B.; Caglio, M.; Croce, M.; Bergui, M.; Tamietto, M.; Mortara, P.; Orsi, L. The recognition of facial emotions in spinocerebellar ataxia patients. Cerebellum 2011, 10, 600-610. [CrossRef] [PubMed]

73. Garrard, P.; Martin, N.H.; Giunti, P.; Cipolotti, L. Cognitive and social cognitive functioning in spinocerebellar ataxia: A preliminary characterization. J. Neurol. 2008, 255, 398-405. [CrossRef] [PubMed]

74. Maschke, M.; Drepper, J.; Kindsvater, K.; Kolb, F.P.; Diener, H.C.; Timmann, D. Fear conditioned potentiation of the acoustic blink reflex in patients with cerebellar lesions. J. Neurol. Neurosurg. Psychiatry 2000, 68, 358-364. [CrossRef] [PubMed]

75. Maschke, M.; Schugens, M.; Kindsvater, K.; Kolb, F.P.; Diener, H.C.; Timmann, D. Fear conditioned changes of heart rate in patients with medial cerebellar lesions. J. Neurol. Neurosurg. Psychiatry 2002, 72, 116-118. [CrossRef] [PubMed]

76. Parente, A.; Manfredi, V.; Tarallo, A.; Salsano, E.; Erbetta, A.; Pareyson, D.; Giovagnoli, A.R. Selective theory of mind impairment and cerebellar atrophy: A case report. J. Neurol. 2013, 260, 2166-2169. [CrossRef] [PubMed]

77. Sokolovsky, N.; Cook, A.; Hunt, H.; Giunti, P.; Cipolotti, L. A preliminary characterisation of cognition and social cognition in spinocerebellar ataxia types 2, 1, and 7. Behav. Neurol. 2010, 23, 17-29. [CrossRef] [PubMed]

78. Critchley, H.D.; Corfield, D.R.; Chandler, M.P.; Mathias, C.J.; Dolan, R.J. Cerebral correlates of autonomic cardiovascular arousal: A functional neuroimaging investigation in humans. J. Physiol. 2000, 523, $259-270$. [CrossRef] [PubMed]

79. Kattoor, J.; Thürling, M.; Gizewski, E.R.; Forsting, M.; Timmann, D.; Elsenbruch, S. Cerebellar contributions to different phases of visceral aversive extinction learning. Cerebellum 2014, 13, 1-8. [CrossRef] [PubMed]

80. Ploghaus, A.; Tracey, I.; Gati, J.S.; Clare, S.; Menon, R.S.; Matthews, P.M.; Rawlins, J.N. Dissociating pain from its anticipation in the human brain. Science 1999, 284, 1979-1981. [CrossRef] [PubMed]

81. Schraa-Tam, C.K.L.; Rietdijk, W.J.R.; Verbeke, W.J.M.I.; Dietvorst, R.C.; Van Den Berg, W.E.; Bagozzi, R.P.; De Zeeuw, C.I. fMRI activities in the emotional cerebellum: A preference for negative stimuli and goal directed behavior. Cerebellum 2012, 11, 233-245. [CrossRef] [PubMed]

82. Singer, T.; Seymour, B.; O'Doherty, J.; Kaube, H.; Dolan, R.J.; Frith, C.D. Empathy for pain involves the affective but not sensory components of pain. Science 2004, 303, 1157-1162. [CrossRef] [PubMed]

83. Utz, A.; Thürling, M.; Ernst, T.M.; Hermann, A.; Stark, R.; Wolf, O.T.; Timmann, D.; Merz, C.Z. Cerebellar vermis contributes to the extinction of conditioned fear. Neurosci. Lett. 2015, 604, 173-177. [CrossRef] [PubMed]

84. Adamaszek, M.; Olbrich, S.; Kirkby, K.C.; Woldag, H.; Willert, C.; Heinrich, A. Event-related potentials indicating impaired emotional attention in cerebellar stroke-A case study. Neurosci. Lett. 2013, 548, $206-211$. [CrossRef] [PubMed]

85. Adamaszek, M.; Kirkby, K.C.; D'Agata, F.; Olbrich, S.; Langner, S.; Steele, C.J.; Sehm, B.; Busse, S.; Kessler, C.; Hamm, A. Neural correlates of disturbed emotional face recognition in cerebellar lesions. Brain Res. 2015, 1613, 1-12. [CrossRef] [PubMed] 
86. Ferrucci, R.; Giannicola, G.; Rosa, M.; Fumagalli, M.; Boggio, P.; Hallett, M.; Zago, S.; Priori, A. Cerebellum and processing of negative facial emotions: Cerebellar transcranial DC stimulation specifically enhances the emotional recognition of facial anger and sadness. Cogn. Emot. 2012, 26, 786-799. [CrossRef] [PubMed]

87. Nisimaru, N. Cardiovascular modules in the cerebellum. Jpn. J. Physiol. 2004, 54, 431-448. [CrossRef] [PubMed]

88. Harper, R.M.; Gozal, D.; Bandler, R.; Spriggs, D.; Lee, J.; Alger, J. Regional brain activation in humans during respiratory and blood pressure challenges. Clin. Exp. Pharmacol. Physiol. 1998, 25, 483-486. [CrossRef] [PubMed]

89. Blood, J.D.; Wu, J.; Chaplin, T.M.; Hommer, R.; Vasquez, L.; Rutherford, H.J.; Mayes, L.C.; Crowley, M.J. The variability heart: High frequency and very low frequency correlates of depressive symptoms in children and adolescents. J. Affect. Disord. 2015, 186, 119-126. [CrossRef] [PubMed]

90. Sacchetti, B.; Scelfo, B.; Strata, P. The cerebellum: Synaptic changes and fear conditioning. Neuroscientist 2005, 11, 217-227. [CrossRef] [PubMed]

91. Tabbert, K.; Stark, R.; Kirsch, P.; Vaitl, D. Dissociation of neural responses and skin conductance reactions during fear conditioning with and without awareness of stimulus contingencies. Neuroimage 2006, 32, 761-770. [CrossRef] [PubMed]

92. Damasio, A.R.; Tranel, D.; Damasio, H.C. Somatic markers and the guidance of behavior: Theory and preliminary testing. In Frontal Lobe Function and Dysfunction; Levin, H.S., Eisenberg, H.M., Benton, L.B., Eds.; Oxford University Press: Oxford, UK, 1991; pp. 217-229; ISBN: 9780195062847.

93. Spyer, K.M. Central nervous control of the cardiovascular system. In Autonomic Failure: A Textbook of Clinical Disorders of the Autonomic Nervous System; Mathias, C.J., Bannister, R., Eds.; Oxford University Press: Oxford, UK, 1999; pp. 45-55; ISBN: 0199666504, 9780199666508.

94. Watson, T.C.; Koutsikou, S.; Cerminara, N.L.; Flavell, C.R.; Crook, J.J.; Lumb, B.M.; Apps, R. The olivo-cerebellar system and its relationship to survival circuits. Front. Neural Circ. 2013, 7, 72. [CrossRef] [PubMed]

95. Koutsikou, S.; Crook, J.J.; Earl, E.V.; Leith, J.L.; Watson, T.C.; Lumb, B.M.; Apps, R. Neural substrates underlying fear-evoked freezing: The periaqueductal grey-cerebellar link. J. Physiol. 2014, 592, 2197-2213. [CrossRef] [PubMed]

96. Azizi, S.A.; Burne, R.A.; Woodward, D.J. The auditory corticopontocerebellar projection in the rat: Inputs to the paraflocculus and midvermis. An anatomical and physiological study. Exp. Brain Res. 1985, 59, $36-49$. [CrossRef] [PubMed]

97. Ruediger, S.; Vittori, C.; Bednarek, E.; Genoud, C.; Strata, P.; Sacchetti, B.; Caroni, P. Learning-related feedforward inhibitory connectivity growth required for memory precision. Nature 2011, 473, 514-518. [CrossRef] [PubMed]

98. Zhu, L.; Scelfo, B.; Hartell, N.A.; Strata, P.; Sacchetti, B. The effects of fear conditioning on cerebellar LTP and LTD. Eur. J. Neurosci. 2007, 26, 219-227. [CrossRef] [PubMed]

99. Sacchetti, B.; Scelfo, B.; Strata, P. Cerebellum and emotional behavior. Neuroscience 2009, 162, 756-762. [CrossRef] [PubMed]

100. Scelfo, B.; Sacchetti, B.; Strata, P. Learning-related long-term potentiation of inhibitory synapses in the cerebellar cortex. Proc. Natl. Acad. Sci. USA 2008, 105, 769-774. [CrossRef] [PubMed]

101. Greve, K.W.; Stanford, M.S.; Sutton, C.; Foundas, A.L. Cognitive and emotional sequelae of cerebellar infarct: A case-report. Arch. Clin. Neuropsychol. 1999, 14, 455-469. [CrossRef] [PubMed]

102. Levisohn, L.; Cronin-Golomb, A.; Schmahmann, J.D. Neuropsychological consequences of cerebellar tumour resection in children: Cerebellar cognitive affective syndrome in a paediatric population. Brain 2000, 123, 1041-1050. [CrossRef] [PubMed]

103. Riva, D.; Giorgi, C. The cerebellum contributes to higher function during development: Evidence from a series of children surgically treated for posterior fossa tumors. Brain 2000, 123, 1051-1061. [CrossRef] [PubMed]

104. Steinlin, M.; Imfeld, S.; Zulauf, P.; Boltshauser, E.; Lövblad, K.O.; Ridolfi Lüthy, A.; Perrig, W.; Kaufmann, F. Neuropsychological long-term sequelae after posterior fossa tumour resection during childhood. Brain 2003, 126, 1998-2008. [CrossRef] [PubMed]

105. Aarsen, F.; Dongen, H.V.; Paquier, P.; Mourik, M.V.; Catsman-Berrevoets, C. Long-term sequelae in children after cerebellar astrocytoma surgery. Neurology 2004, 62, 1311-1316. [CrossRef] [PubMed] 
106. Ozimek, A.; Richter, S.; Hein-Kropp, C.; Schoch, B.; Gorissen, B.; Kaiser, O.; Gizewski, E.; Ziegler, W.; Timmann, D. Cerebellar mutism-Report of four cases. J. Neurol. 2004, 251, 963-972. [CrossRef] [PubMed]

107. Richter, S.; Schoch, B.; Kaiser, O.; Groetschel, H.; Dimitrova, A.; Hein-Kropp, C.; Gizewski, E.R.; Timmann, D. Behavioral and affective changes in children and adolescents with chronic cerebellar lesions. Neurosci. Lett. 2005, 381, 102-107. [CrossRef] [PubMed]

108. Tavano, A.; Grasso, R.; Gagliardi, C.; Triulzi, F.; Bresolin, N.; Fabbro, F.; Borgatti, R. Disorders of cognitive and affective development cerebellar malformations. Brain 2007, 130, 2646-2660. [CrossRef] [PubMed]

109. Marien, P.; Verslegers, L.; Moens, M.; Dua, G.; Herregods, P.; Verhoeven, J. Posterior fossa syndrome after cerebellar stroke. Cerebellum 2013, 12, 686-691. [CrossRef] [PubMed]

110. Parvizi, J.; Anderson, S.W.; Martin, C.O.; Damasio, H.; Damasio, A.R. Pathological laughter and crying: A link to the cerebellum. Brain 2001, 124, 1708-1719. [CrossRef] [PubMed]

111. Famularo, G.; Corsi, F.; Minisola, G.; De Simone, C.; Nicotra, G. Cerebellar tumour presenting with pathological laughter and gelastic syncope. Eur. J. Neurol. 2007, 14, 940-943. [CrossRef] [PubMed]

112. Parvizi, J.; Joseph, J.; Press, D.Z.; Schmahmann, J.D. Pathological laughter and crying in patients with multiple system atrophy-cerebellar type. Mov. Disord. 2007, 22, 798-803. [CrossRef] [PubMed]

113. Schmahmann, J.D. An emerging concept. The cerebellar contribution to higher function. Arch. Neurol. 1991, 48, 1178-1187. [CrossRef] [PubMed]

114. Timmann, D.; Drepper, J.; Frings, M.; Maschke, M.; Richter, S.; Gerwig, M.; Kolb, F.P. The human cerebellum contributes to motor, emotional and cognitive associative learning. A review. Cortex 2010, 46, 845-857. [CrossRef] [PubMed]

115. Ramnani, N. The primate cortico-cerebellar system: Anatomy and function. Nat. Rev. Neurosci. 2006, 7, 511-522. [CrossRef] [PubMed]

116. Vuilleumier, P.; Pourtois, G. Distributed and interactive brain mechanisms during emotion face perception: Evidence from functional neuroimaging. Neuropsychologia 2007, 45, 174-194. [CrossRef] [PubMed]

117. Kanwisher, N.; McDermott, J.; Chun, M.M. The fusiform face area: A module in human extrastriate cortex specialized for face perception. J. Neurosci. 1997, 17, 4302-4311. [CrossRef] [PubMed]

118. Adolphs, R. Neural systems for recognizing emotion. Curr. Opin. Neurobiol. 2002, 12, 169-177. [CrossRef]

119. Schupp, H.T.; Ohman, A.; Junghofer, M.; Weike, A.I.; Stockburger, J.; Hamm, A.O. The facilitated processing of threatening faces: An ERP analysis. Emotion 2004, 4, 189-200. [CrossRef] [PubMed]

120. Phillips, M.L.; David, A.S. Facial processing in schizophrenia and delusional misidentification: Cognitive neuropsychiatric approaches. Schizophr. Res. 1995, 17, 109-114. [CrossRef]

121. Frank, M.G.; Stennett, J. The forced-choice paradigm and the perception of facial expressions of emotion. J. Pers. Soc. Psychol. 2001, 80, 75-85. [CrossRef] [PubMed]

122. Grossmann, T.; Johnson, M.H. The development of the social brain in human infancy. Eur. J. Neurosci. 2007, 25, 909-919. [CrossRef] [PubMed]

123. Ghashghaei, H.T.; Hilgetag, C.C.; Barbas, H. Sequence of information processing for emotions based on the anatomic dialogue between prefrontal cortex and amygdala. Neuroimage 2007, 34, 905-923. [CrossRef] [PubMed]

124. Rudebeck, P.H.; Bannerman, D.M.; Rushworth, M.F. The contribution of distinct subregions of the ventromedial frontal cortex to emotion, social behavior, and decision making. Cogn. Affect. Behav. Neurosci. 2008, 8, 485-497. [CrossRef] [PubMed]

125. LeDoux, J.E. The Emotional Brain: The Mysterious Underpinnings of Emotional Life; Simon \& Schuster: New York, NY, USA, 1996; ISBN: 9781439126387.

126. LeDoux, J. The amygdala. Curr. Biol. 2007, 17, R868-R874. [CrossRef] [PubMed]

127. Wallentin, M.; Nielsen, A.H.; Vuust, P.; Dohn, A.; Roepstorff, A.; Lund, T.E. Amygdala and heart rate variability responses from listening to emotionally intense parts of a story. Neuroimage 2011, 58, 963-973. [CrossRef] [PubMed]

128. Bishop, S.J. Neurocognitive mechanisms of anxiety: An integrative account. Trends Cogn. Sci. 2007, 11, 307-316. [CrossRef] [PubMed]

129. Damasio, A. The Feeling of What Happens: Body and Emotion in the Making of Consciousness; Harcourt Brace: New York, NY, USA, 1999; ISBN: 10: 0151003696. 
130. Pandya, D.N.; Yeterian, E.G. The anatomical substrates of emotional behavior: The role of the cerebral cortex. In Handbook of Neuropsychology; Emotional Behavior and its Disorders; Boller, F., Grafman, J., Eds.; Elsevier: New York, NY, USA, 2000; Volume 5, ISBN: 0444503676, 9780444503671.

131. Clausi, S.; Lupo, M.; Aloise, F.; Contento, M.P.; Pizzamiglio, L.; Molinari, M.; Leggio, M. Depression disorder in patients with cerebellar damage: Awareness of mood state. Manuscript in preparation.

132. Lazarus, R. Emotion and Adaptation; Oxford University Press: New York, NY, USA, 1991; ISBN: 0190281782 , 9780190281786.

133. Lazarus, R.; Smith, C. Appraisal components, core relational themes, and the emotions. In Appraisal and Beyond; Frijda, N., Ed.; Erlbaum: Hillsdale, NJ, USA, 1993; pp. 233-270. ISBN: 0863779158, 9780863779152.

134. Damasio, A.R.; Grabowski, T.J.; Bechara, A.; Damasio, H.; Ponto, L.L.; Parvizi, J.; Hichwa1, R.D. Subcortical and cortical brain activity during the feeling of self-generated emotions. Nat. Neurosci. 2000, 3, 1049-1056. [CrossRef] [PubMed]

135. Critchley, H. Neural mechanisms of autonomic, affective, and cognitive integration. J. Comp. Neurol. 2005, 493, 154-166. [CrossRef] [PubMed]

136. Stephens, C.L.; Christie, I.C.; Friedman, B.H. Autonomic specificity of basic emotions: Evidence from pattern classification and cluster analysis. Biol. Psychol. 2010, 84, 463-473. [CrossRef] [PubMed]

137. Seth, A.K. Interoceptive inference, emotion, and the embodied self. Trends Cogn. Sci. 2013, 17, 565-573. [CrossRef] [PubMed]

138. Posner, J.; Russell, J.A.; Peterson, B.S. The circumplex model of affect: An integrative approach to affective neuroscience, cognitive development, and psychopathology. Dev. Psychopathol. 2005, 17, 715-734. [CrossRef] [PubMed]

139. Colibazzi, T.; Posner, J.; Wang, Z.; Gorman, D.; Gerber, A.; Yu, S.; Zhu, H.; Kangarlu, A.; Duan, Y.; Russell, J.A.; et al. Neural systems subserving valence and arousal during the experience of induced emotions. Emotion 2010, 10, 377-389. [CrossRef] [PubMed]

140. Prinz, J. Gut Reactions: A Perceptual Theory of Emotion; Oxford University Press: New York, NY, USA, 2006.

141. Sizer, L. Towards a computational theory of mood. Br. J. Philos. Sci. 2000, 51, 743-770. [CrossRef]

142. Oatley, K.; Johnson-Laird, P. Cognitive approaches to emotions. Trends Cogn. Sci. 2014, 18, $134-140$. [CrossRef] [PubMed]

143. Snow, W.M.; Stoesz, B.M.; Anderson, J.E. The cerebellum in emotional processing: Evidence from human and non-human animals. AIMS Neurosci. 2014, 1, 96-119. [CrossRef]

144. Molinari, M.; Chiricozzi, F.R.; Clausi, S.; Tedesco, A.M.; De Lisa, M.; Leggio, M.G. Cerebellum and detection of sequences, from perception to cognition. Cerebellum 2008, 7, 611-615. [CrossRef]

145. Leggio, M.G.; Chiricozzi, F.R.; Clausi, S.; Tedesco, A.M.; Molinari, M. The neuropsychological profile of cerebellar damage: The sequencing hypothesis. Cortex 2011, 47, 137-144. [CrossRef] [PubMed]

146. Molinari, M.; Restuccia, D.; Leggio, M.G. State estimation, response prediction, and cerebellar sensory processing for behavioral control. Cerebellum 2009, 8, 399-402. [CrossRef] [PubMed]

147. Ito, M. Control of mental activities by internal models in the cerebellum. Nat. Rev. Neurosci. 2008, 9, $304-313$. [CrossRef] [PubMed]

148. Leggio, M.; Molinari, M. Cerebellar sequencing: A trick for predicting the future. Cerebellum 2015, 14, 35-38. [CrossRef] [PubMed]

149. Paquette, S.; Mignault Goulet, G.; Rothermich, K. Prediction, attention and unconscious processing in hierarchical auditory perception. Front. Psychol. 2013, 4, 955-956. [CrossRef] [PubMed]

150. Clausi, S.; Aloise, F.; Contento, M.P.; Pizzamiglio, L.; Molinari, M.; Leggio, M. Monitoring mood states in everyday life: A new device for patients with cerebellar ataxia. Psychiatry Res. 2014, 220, 719-721. [CrossRef] [PubMed]

151. D'Angelo, E.; Casali, S. Seeking a unified framework for cerebellar function and dysfunction: From circuit operations to cognition. Front. Neural Circuits 2013, 6, 116. [CrossRef] [PubMed]

152. Ito, M. Cerebellar circuitry as a neuronal machine. Prog. Neurobiol. 2006, 78, 272-303. [CrossRef] [PubMed]

153. Andreasen, N.C.; Paradiso, S.; O'Leary, D.S. "Cognitive dysmetria" as an integrative theory of schizophrenia: A dysfunction in cortical-subcortical-cerebellar circuitry? Schizophr. Bull. 1998, 24, 203-218. [CrossRef] [PubMed]

154. Beyer, J.L.; Krishnan, K.R. Volumetric brain imaging findings in mood disorders. Bipolar Disord. 2002, 4, 89-104. [CrossRef] [PubMed] 
155. Olivito, G.; Clausi, S.; Laghi, F.; Tedesco, A.M.; Baiocco, R.; Mastropasqua, C.; Molinari, M.; Cercignani, M.; Bozzali, M.; Leggio, M. Resting-State Functional Connectivity Changes between Dentate Nucleus and Cortical Social Brain Regions in Autism Spectrum Disorders. Cerebellum 2017, 16, 283-292. [CrossRef] [PubMed]

156. Blakemore, S.J.; Smith, J.S.; Steel, R.; Johnstone, E.C.; Frith, C.D. The perception of self-produced sensory stimuli in patients with auditory hallucinations and passivity experiences: Evidence for breakdown in self-monitoring. Psychol. Med. 2000, 30, 1131-1139. [CrossRef] [PubMed]

(C) 2017 by the authors. Licensee MDPI, Basel, Switzerland. This article is an open access article distributed under the terms and conditions of the Creative Commons Attribution (CC BY) license (http:/ / creativecommons.org/licenses/by/4.0/). 